\title{
Wybrane problemy z działalności wydawniczej Towarzystwa Nauczycieli Szkół Średnich i Wyższych w dwudziestoleciu międzywojennym
}

Towarzystwo Nauczycieli Szkół Średnich i Wyższych (TNSW), z siedzibą Zarządu Głównego w Warszawie, zawiązało się w dniach 28-30 grudnia 1919 roku przez połączenie, istniejącego od 1884 we Lwowie, Towarzystwa Nauczycieli Szkół Wyższych ze Stowarzyszeniem Nauczycielstwa Polskiego, założonym w 1905 roku w Warszawie. Było organizacją zawodową i do 1929 roku należało do Polskiej Konfederacji Pracowników Umysłowych, a później do Ogólnego Zrzeszenia Związków i Stowarzyszeń Pracowników Państwowych Rzeczypospolitej Polskiej, a także do Międzynarodowego Biura Narodowych Towarzystw Nauczycieli Szkół Średnich w Paryżu². TNSW miało na celu doskonalenie swoich członków w sferze zawodowej, a także obronę ich interesów, niesienie pomocy materialnej, wsparcie moralne. Ponadto dążyło do pogłębiania wiedzy, do jej popularyzowania. Zamierzało czuwać nad należytym rozwojem szkolnictwa ${ }^{3}$. Na czele Towarzystwa stał Zarząd Główny. Podlegały mu Zarządy Okręgowe. Teren ich działalności pokrywał się z okręgami kuratoriów. Zarządom Okręgowym podlegały Koła Miejscowe, których było od 150 do 200. W obrębie Towarzystwa istniały trzy główne sekcje: seminariów nauczycielskich, szkół zawodowych i dyrektorów

* Dr, Uniwersytet Opolski, Wydział Historyczno-Pedagogiczny, Instytut Historii, 45-084 Opole, ul. Strzelców Bytomskich 2.

${ }^{1}$ B. Łuczyńska, Koło krakowskie TNSW na tle prac Towarzystwa Nauczycieli Szkół Średnich i Wyższych 1884-1939, Kraków 1991, s. 31, 95.

${ }^{2}$ A. Kołodziejczyk, Towarzystwo Nauczycieli Szkół Średnich i Wyższych, [w:] Encyklopedia historii Drugiej Rzeczypospolitej, red. A. Garlicki, Z. Landau, W. Roszkowski, P. Stawecki, J. Tomaszewski, Warszawa 1999, s. 459.

${ }^{3}$ Nasze stanowisko, „Przegląd Pedagogiczny” 1921, nr 2-3, s. 47-48; J. Szafran, Dla dobra polskiej szkoły. Towarzystwo Nauczycieli Szkół Średnich i Wyższych i jego funkcje społeczno-oświatowe w Drugiej Rzeczypospolitej, Poznań 2010, s. 11-12. 
szkół państwowych. Z kolei w kołach miejscowych istniały sekcje, których celem było wspieranie wykształcenia naukowego i pedagogicznego członków ${ }^{4}$. Wraz z kształtowaniem się granic II Rzeczypospolitej powstawały nowe okręgi i koła5. W 1924 roku do TNSW należało około siedmiu tysięcy, a w 1939 roku około pięciu tysięcy członków6. Towarzystwo prowadziło i utrzymywało: Muzeum Szkolne we Lwowie, Bibliotekę Naukowo-Pedagogiczną w Warszawie, Instytut Pedagogiczny w Łodzi. Biblioteki i czytelnie posiadały też poszczególne koła miejscowe. Oficjalnym organem TNSW był „Przegląd Pedagogiczny”, ale rolę tę pełniło też czasopismo „Muzeum”. Czołowi działacze TNSW to: Paweł Sosnowski, Ludwik Jaxa-Bykowski, Jan Kornecki, Tadeusz Mikułowski, Kazimierz Brończyk, Władysław Kopaczewski, Stefan Kwiatkowski, Wacław Sierpiński, Władysław Tatarkiewicz. Towarzystwo działało nieprzerwanie do wybuchu II wojny światowej, a później w warunkach konspiracyjnych organizowało tajne nauczanie ${ }^{7}$. Działalność Towarzystwa była już wielokrotnie poddawana analizie. Dokonywały tego: Janina Chodakowska ${ }^{8}$, Barbara Łuczyńska ${ }^{9}$, a ostatnio Joanna Szafran ${ }^{10}$.

Jeszcze przed odzyskaniem niepodległości, na I Walnym Zgromadzeniu Towarzystwa Nauczycieli Szkół Wyższych uchwalono powołanie czasopisma „Muzeum” (wydawanego we Lwowie od 1886 roku) jako własnego organu Towarzystwa, mającego docierać do członków. Podstawą jego finansowania były składki członkowskie, a pismo rozsyłano bezpłatnie ${ }^{11}$. Po połączeniu Towarzystwa Nauczycieli Szkół Wyższych i Stowarzyszenia Nauczycielstwa Polskiego, prezesem wybrano Pawła Sosnowskiego. Właśnie wtedy podstawowym organem prasowym Towarzystwa został „Przegląd Pedagogiczny” (ukazywał się w zaborze rosyjskim od 1882 roku i został przejęty przez Stowarzyszenie Nauczycielstwa Polskiego), którego redaktorami byli: Bogdan Nawroczyński, później Tadeusz Ła-

${ }^{4}$ A. Kołodziejczyk, Towarzystwo Nauczycieli Szkół Średnich i Wyższych..., s. 459.

5 Kronika Towarzystwa, „Sprawy Towarzystwa Nauczycieli Szkół Średnich i Wyższych (TNSW)”. Dodatek tygodniowy do „Przeglądu Pedagogicznego” 1923, nr 16, s. 247-256.

${ }^{6}$ A. Kołodziejczyk, Towarzystwo Nauczycieli..., s. 459.

7 M. Tazbir, TNSW w okresie okupacji, „Przegląd Historyczno-Oświatowy” 1947, nr 1; tenże, TNSW w latach wojny 1939-1945, „Przegląd Historyczno-Oświatowy” 1947, nr 3-4; tenże, Z dziejów dawnego Towarzystwa Nauczycieli, „Życie i Myśl” 1967, nr 6, s. 63-79.

8 J. Chodakowska, Towarzystwo Nauczycieli Szkół Wyższych i jego udział w reformie szkół średnich w Polsce Międzywojennej, „Rozprawy z Dziejów Oświaty” 1986, t. XXIX, s. 69-106; taż, Udział Towarzystwa Nauczycieli Szkół Wyższych w walce o polską szkołę średnią w Galicji w latach 1884-1914, „Rozprawy z Dziejów Oświaty” 1984, t. XXVI, s. 141-172; taż, Towarzystwo Nauczycieli Szkół Wyższych i jego udział w reformie szkół średnich w Polsce międzywojennej, [w:] Studia z dziejów edukacji, red. J. Miąso, Warszawa 1994, s. 304-306.

${ }^{9}$ B. Łuczyńska, Koło krakowskie TNSW na tle prac Towarzystwa...; taż, Towarzystwo Nauczycieli Szkół Wyższych wobec problemu nauczycieli szkół średnich (1884-1918), „Rocznik Komisji Nauk Pedagogicznych" 1984, t. XXXII, s. 25-50; taż, Krakowskie Koło TNSW wobec problemów nauczycielskich 1884-1918, „Przegląd Historyczno-Oświatowy” 1985, nr 2, s. 267-294; taż, Udział nauczycieli szkół średnich zrzeszonych w TNSW w reformowaniu szkolnictwa galicyjskiego (1884-1918), [w:] Nauczyciele szkół średnich w XIX i XX wieku jako grupa społeczna $i$ ich wkład w kulturę polską, red. M. Chamcówna, S. Walasek, Wrocław 1995.

10 J. Szafran, Dla dobra polskiej szkoły..., s. 12.

11 B. Łuczyńska, Koło krakowskie TNSW na tle prac Towarzystwa..., s. 18; J. Szafran, Dla dobra polskiej szkoły..., s. 150. 
zowski, od 1922 roku - Lucjan Zarzecki, a następnie: Henryk Galle i Maksymilian Tazbir (pismo początkowo było miesięcznikiem, od 1922 roku kwartalnikiem, od 1926 tygodnikiem, a od 1933 dwutygodnikiem). Status oficjalnego organu prasowego TNSW utrzymano także w przypadku „Muzeum”, co było przejawem rozwiązania kompromisowego podczas łączenia się dwóch towarzystw. „Muzeum” od 1920 roku było kwartalnikiem (redaktorzy to: Jerzy Dunin-Wąsowicz, Ludwik Jaxa-Bykowski, Piotr Dąbrowski, Władysław Olszewski, Kazimierz Brończyk) ${ }^{12}$. W obu czasopismach starano się zachować podział kompetencji. „Przegląd Pedagogiczny” informował o sprawach organizacyjno-związkowych i zajmował się problematyką szkół średnich, na jego łamach przedstawiano sposoby nauczania w innych krajach, omawiano nowe metody, starano się znaleźć sposób na polepszenie pozycji zawodowej nauczyciela w Polsce. „Muzeum” zajmowało się problematyką naukowo-pedagogiczną, szczególnie dydaktyką w szkołach średnich ${ }^{13}$.

Ponadto wraz z „Przeglądem Pedagogicznym” TNSW wydawało jego dodatki, w latach 1922-1924 tygodnik „Sprawy Towarzystwa”, a od 1933 roku kwartalnik „Kultura i Wychowanie” pod redakcją Bogdana Suchodolskiego, w którym prezentowano problematykę związaną ze współczesnymi zagadnieniami kultury. Wspierano wydawanie czasopism o tematyce specjalistycznej: „Pedagogium” (od 1925 roku red. Antoni Mikulski), które dotyczyło seminariów nauczycielskich, „Szkolnictwo Zawodowe”, „Wychowanie Fizyczne” (red. Eugeniusz Piasecki), "Przegląd Matematyczno-Fizyczny” (red. Stefan Straszewicz i Władysław Woytowicz), „Czasopismo Geograficzne” (red. J. Jurczyński), literacko-pedagogiczny „Przegląd Humanistyczny” ukazujący się w latach 1920-1930 (red. Wiktor Wąsik). Dla młodzieży szkolnej wydawano tygodnik "Iskry” (red. Władysław Kopczewski), czasopismo popularnonaukowe, skupiające się na popularyzacji wiedzy przyrodniczej, techniki, literatury, geografii ${ }^{14}$. „Iskry” dostały srebrny medal na Powszechnej Wystawie Krajowej w Poznaniu w 1929 roku i Grand Prix na Światowej Wystawie w Paryżu w 1938 roku. Wydawano „Encyklopedię Wychowawczą”. Ponadto TNSW było wydawcą fachowych poradników dla nauczycieli, podręczników szkolnych, współdziałało z władzami w zakresie wydawania podobnych wydawnictw i recenzowało je ${ }^{15}$.

Jak można zauważyć, od początku istnienia działalność wydawnicza dla TNSW była bardzo ważna, a z czasem rozszerzała się. Sporo inwestowano. Jeszcze w 1916 roku powstała „Książnica Polska TNSW”. Ważnym zadaniem w TNSW było wydawanie podręczników. Święcono sukcesy, ale były też niepowodzenia. Do jednego z konfliktów doszło po przejęciu kontroli nad Wydawnictwem "Oświata” w 1921 roku. Po dwóch latach od przejęcia Komisja Wydawnictwa „Oświata”, w osobach: Heleny Jeziorańskiej, Hanny Dobrowolskiej, Marii Rostalskiej i Rozalii M. Brzezińskiej, zażądała zwrotu wydawnictwa, argumentując:

12 J. Szafran, Dla dobra polskiej szkoły..., s. 150-151; 1918-1938, „Przegląd Pedagogiczny” 1938, nr 23, s. 333-334.

${ }^{13}$ B. Łuczyńska, Koło krakowskie TNSW na tle prac Towarzystwa..., s. 124.

14 Tamże, s. 125.

15 Tamże; J. Szafran, Dla dobra polskiej szkoły..., s. 157. 
Wydawnictwo to bowiem pomieszczone w „Książnicy Polskiej” zamiast rozwijać się, zamiera. Pierwszą tego przyczyną było zaraz po przejęciu zamknięcie sprzedaży książek na kilka miesięcy, przez co obieg wszystkich książek, a zwłaszcza podręczników został zatamowany. Otrzymawszy zasadniczą zgodę TNSW na wycofanie książek Komitet „Oświaty” rozpoczął bezpośrednie pertraktacje z Adm.[inistracją] „Książnicy”. Rozrachunki otrzymane z „Książnicy” od 6 lipca b.r. okazały się jednak niemożliwe do przyjęcia:

Z racji bezprawnego zastosowania mnożnika księgarskiego do długu „Oświaty”, który to dług powstał bez wiedzy, bez porozumienia z Komitetem i bez podania warunków na jakich „Książnica” wykłada pieniądze na wydatki „Oświaty”. O długu dowiedział się Komitet z rachunków nadesłanych 21 marca b.r.

Dług zapoczątkowano jeszcze w roku 1921 a to skutkiem wydrukowania we Lwowie, bez wiedzy i zlecenia Komitetu 3 książek, których część dotąd jeszcze nie została sprowadzona ze Lwowa.

Zarządzono również, bez porozumienia się z Komitetem „Oświaty”, oprawę gwiazdkową znacznej ilości książek co pociągnęło wydatek kilku milionów [marek polskich], a książki nie poszły.

Na pokrycie długu posiada „Oświata” zapas książek, z których należałoby pobrać procentowo, nie ryczałtem pewne wydawnictwa, jak np. podręczniki, czego sobie życzy „Książnica”. [...] Wobec tego, że każdy dzień zwłoki powoduje poważne straty dla wydawnictwa, prosimy uprzejmie Zarząd TNSW o jak najspieszniejsze ustalenie warunków likwidacji możliwych dla nas do przyjęcia ${ }^{16}$.

Niestety, nie zachowały się kolejne dokumenty, obrazujące dalszy przebieg negocjacji.

W 1923 roku „Książnica Polska TNSW” zmieniła nazwę na „Książnica Atlas TNSW". Zmiana nazwy łączyła się z nowym podziałem udziałów w spółce akcyjnej i wyborem nowego Zarządu. Towarzystwo walczyło o utrzymanie dotychczasowej silnej pozycji w Radzie Nadzorczej spółki. Aby to osiągnąć, prowadzono negocjacje $z$ nowymi akcjonariuszami. Nie było to łatwe zadanie. $W$ specjalnym sprawozdaniu, sporządzonym właśnie z przebiegu tych pertraktacji, czytamy:

Nadzwyczajne Wal.[ne] Zgrom.[adzenie] „Książnicy” miało się odbyć dnia 15 XII 1923. Akcje „Książnicy” nie były jeszcze wydane. Do przeprowadzenia transakcji tj. kupna akcji „Atlasu” za pieniądze uzyskane ze sprzedaży naszej parceli budowlanej we Lwowie nie było czasu, a nadto kupno akcji w takiej chwili było dla nas niekorzystne. Chodziło zresztą o co innego, co wszyscy rozumieli [...]. Zależało nam bowiem na tym, by Zarząd Główny TNSW miał odpowiednią ilość członków Rady Nad.[zorczej] gdyż wiedzieliśmy, że już na najbliższym Walnym Zgromadzeniu „Książnicy” w marcu lub kwietniu po wylosowaniu 1/3 członków Rady Nad.[zorczej] w myśl § 21 statutu Ski [Spółki] Akcyjnej liczba reprezentantów Zarządu Gł.[ównego] TNSW w Rad.[zie] Nad.[zorczej] Książnicy zmaleje tak, że wpływ TNSW spadnie prawie do zera. Do Rady Nad.[zorczej] weszliby niezawodnie nauczyciele i członkowie TNSW jednak tacy, jakich by sobie życzyła dyrekcja Książnicy a nie Zarząd Gł.[ówny] TNSW. Do przeprowadzenia porozumienia niewiele czasu zostawało, a Dyrekcja Książnicy wywierała wówczas na nas nacisk, by szybko sprawę załatwić koniecznie przed 15 grudnia. Zażądaliśmy wtedy zwołania Rady Nad. Przed 15 XII 1923. Zarząd zaś Gł.[ówny] zażądał [...] przesunięcia terminu na czas późniejszy. Odłożono Wal.[ne] Zgr.[omadzenie] na 19 stycznia 1924. Rozpoczęły się pertraktacje ${ }^{17}$.

Podczas Walnego Zgromadzenia reprezentanci Zarządu Głównego TNSW, Stefan Kuczyński, Franciszek Oziębły i Józef Ujejski, złożyli oświadczenie, w któ-

${ }^{16}$ AAN, Towarzystwo Nauczycieli Szkół Średnich i Wyższych, sygn. 240, Pismo Komisji Wydawniczej „Oświata” do Zarządu Towarzystwa Nauczycieli Szkół Średnich i Wyższych w Warszawie z 20 [?] VIII 1923 r., k. 27-28.

${ }^{17}$ AAN, Towarzystwo Nauczycieli Szkół Średnich i Wyższych, sygn. 171, Sprawozdanie z przebiegu i wyniku pertraktacji między TNSW a Książnicą Polską z 16 II 1924 r., k. 46. 
rym sprzeciwili się fuzji „Książnicy” z „Atlasem”, postanowili głosować przeciw zmianie nazwy firmy i emisji 25000 akcji przeznaczonych na wykupienie 100000 akcji „Atlasu”. Swoją decyzję argumentowali:

1. Sądzimy, że obydwie spółki jako jednostki gospodarcze mniejsze sprawniej funkcjonować i lepiej rozwijać się będą.

2. Wobec obecnego zastoju na rynku handlowym dla produktów wytwarzanych przez Atlas po fuzji musiałaby Książnica ogromny kapitał unieruchomić na dłuższy czas w Atlasie, na czym może ucierpieć sprawność wydawnictw podręczników szkolnych, co jest głównym celem Książnicy.

3. Nadto, przez sfery nauczycielskie i szeroki ogół publiczności identyfikowana jest Książnica z TNSW. Jest przekonanie, że TNSW ma decydujący wpływ w Książnicy. Niestety, tak nie jest, a po fuzji i po wyborach najbliższych do rady Nad.[zorczej], wpływ ten spadnie prawie do zera. Godząc się swego czasu w zasadzie na fuzję Książnicy z Atlasem, mieliśmy nadzieję, że odpowiedni i pożądany wpływ Towarzystwa naszego będzie zapewniony. Jednakże usiłowania i dobra nasza wola i skłonność do koncesji pozostały bez skutku. Głosowaniem dzisiejszym chcemy zaznaczyć, że moralnej i ideowej odpowiedzialności za działalność nowej spółki Tow.[arzystwo] Naucz.[ycieli] Szkół Wyższych wziąć na siebie nie możemy ${ }^{18}$.

Tak zdecydowana postawa przedstawicieli Zarządu Głównego TNSW wpłynęła na kształt nowej spółki „Książnica-Atlas”. Zawarto porozumienie, w wyniku którego połowę członków Rady Nadzorczej desygnował Zarząd Główny TNSW. W Regulaminie dla członków Rady Nadzorczej już w pierwszym artykule informowano, że „Książnica-Atlas” to spółka akcyjna, której założycielem były: Bank Gospodarstwa Krajowego, geograf prof. Eugeniusz Romer i TNSW, a znajduje się w niej „nie tylko majątek TNSW, przez jedno pokolenie nauczycielskie zapracowany, lecz także ulokowane są w tej instytucji wartości ideowe Towarzystwa"19.

W Regulaminie tym stwierdzano, że do obowiązków członków TNSW, zasiadających w Radzie Nadzorczej spółki, należy czuwanie nad wzrostem majątku Towarzystwa i członków - akcjonariuszy spółki, ale także są oni odpowiedzialni za wartości ideowe i poziom naukowy wydawnictw „Książnicy-Atlasu”. Zarząd Główny TNSW żądał od swoich członków sprawozdań ze stanu interesów spółki oraz z prowadzonej przez nią polityki wydawniczej. Instrukcje Zarządu Głównego TNSW obowiązywały członków Rady Nadzorczej, kiedy zostały zawarte w obecności wszystkich członków Rady ${ }^{20}$.

W następnych latach spółka świetnie się rozwijała i przynosiła spore zyski $^{21}$. W 1929 roku otrzymała złoty medal na Powszechnej Wystawie Krajowej w Poznaniu22. Umacniano współpracę pomiędzy spółką a innymi instytucjami związanymi z TNSW. W dniu 16 stycznia 1931 roku „Książnica-Atlas Zjednoczone

${ }^{18}$ AAN, Towarzystwo Nauczycieli Szkół Średnich i Wyższych, sygn. 171, Oświadczenie Reprezentantów Zarządu Głównego TNSW dr. Kuczyńskiego, prof. Oziębłego i prof. Ujejskiego na nadzwyczajnym Walnym Zgromadzeniu akcjonariuszy Książnicy dnia 19 | 1924 r., k. 54.

${ }^{19}$ AAN, Towarzystwo Nauczycieli Szkół Średnich i Wyższych, sygn. 171, Regulamin dla członków Rady Nadzorczej „Książnicy-Atlasu” uchwalony przez Zarząd Główny TNSW dnia 8 stycznia 1928 r., k. 76.

20 Tamże.

${ }^{21}$ W. Topoliński, Z działalności Książnicy-Atlasu TNSW. Sprawozdanie z posiedzenia Rady Nadzorczej Książnicy-Atlasu TNSW, „Przegląd Pedagogiczny” 1931, nr 9, s. 227.

22 J. Szafran, Dla dobra polskiej szkoły..., s. 157. 
Zakłady Kartograficzne i Wydawnicze Towarzystwa Nauczycieli Szkół Średnich i Wyższych, Spółka Akcyjna", reprezentowana przez dra Jana Piątka i Tadeusza Sierzputowskiego, przesłała do Redakcji „Przeglądu Pedagogicznego” pismo, do którego załączono umowę. Określała ona wzajemne świadczenia, m.in. chodziło o zamieszczanie recenzji wydawnictwa „Książnica-Atlas” w „Przeglądzie Pedagogicznym". Przypominano, że redaktor czasopisma Henryk Galle, w dniu 16 stycznia 1931 roku na spotkaniu z dyrekcją spółki, obiecał zamieszczać recenzje, zwłaszcza tych publikacji, które mogą zainteresować większość nauczycielii $^{23}$. Postanowiono więc wzmocnić reklamę wydawnictw spółki „Książnica-Atlas TNSW", pomimo tego że od lat zamawiała ogłoszenia w czasopismach TNSW. Pojawiały się też liczne informacje o innych formach jej działalności, jak np. ufundowanie stypendiów dla uczniów ${ }^{24}$.

Silne związki TNSW z „Książnicą-Atlas” umacniała obecność przedstawiciela spółki w Zarządzie Głównym Towarzystwa, np. w 1939 roku był nim Tadeusz Sierzputowski ${ }^{25}$.

W wydawnictwach nie brakowało też nieporozumień, zawirowań i kłopotów. Czasem były to sprawy drobne, jak np. utyskiwania Redakcji „Przeglądu Pedagogicznego" na brak odpowiedniej okładki pisma. W dniu 13 marca 1929 roku członkowie Redakcji, Leon Płoszewski i Włodzimierz Topoliński, stwierdzali z żalem, że „W preliminarzu budżetowym na rok 1929 nie uwzględniono pozycji na okładkę dla »Przeglądu Ped.[agogicznego]«. [...] [Zwrócili] uwagę na to, że brak okładki b.[ardzo] szkodliwie odbija się na wyglądzie zewnętrznym »Przeglądu Pedagogicznego«. Jest to jedyne pismo nauczycielskie w formacie 8-ki bez okładki, co jest tym boleśniejsze, że nawet pisma wydawane przez sekcje autonomiczne TNSW ukazują się z okładką. [Redaktorzy] ponawiają z naciskiem prośbę, by Prezydium Zarządu Gł.[ównego] zaczęło wreszcie dbać o szatę zewnętrzną swych wydawnictw"26.

Inne problemy, chodź o charakterze przejściowym, mogły spowodować sporo zamieszania w pracach redakcji. Przykładem może być incydent z 1933 roku, związany z pismem „Muzeum”. W dniach 12-13 stycznia odbyło się Walne Zgro-

${ }^{23}$ AAN, Towarzystwo Nauczycieli Szkół Średnich i Wyższych, sygn. 240, Pismo Jana Piątka i Tadeusza Sierzputowskiego z Filii w Warszawie Książnicy-Atlas Zjednoczonych Zakładów Kartograficznych i Wydawniczych TNSW Spółka Akcyjna do Redaktora „Przeglądu Pedagogicznego” Henryka Galle z 16 | 1931 r., k. 37.

${ }^{24}$ AAN, Towarzystwo Nauczycieli Szkół Średnich i Wyższych, sygn. 240, Pismo Jana Piątka i Tadeusza Sierzputowskiego z Filii w Warszawie Książnicy-Atlas Zjednoczonych Zakładów Kartograficznych i Wydawniczych TNSW Spółka Akcyjna do Redaktora „Przeglądu Pedagogicznego" Maksymiliana Tazbira z 23 V 1936 r., k. 130; tamże, Pismo Administracji „Przeglądu Pedagogicznego” do Książnicy-Atlas, Państwowego Wydawnictwa Książek Szkolnych, Ossolineum, Księgarni Jakubowskiego we Lwowie, Księgarni M. Arcta z 10 VIII 1939 r., k. 408 (w piśmie informowano o zamiarze wydania pierwszego powakacyjnego numeru pisma - w dniu 1 września 1939 roku pytano też, czy wymienione wydawnictwa zechcą zamieścić w nim ogłoszenia o nowych podręcznikach szkolnych). Zob. też „Przegląd Pedagogiczny” 1927, nr 2, s. 56.

25 Skład Zarządu Głównego, Głównej Komisji Rewizyjnej i Głównej Komisji Rozjemczej, „Przegląd Pedagogiczny" 1939, nr 7-8, s. 112.

${ }^{26}$ AAN, Towarzystwo Nauczycieli Szkół Średnich i Wyższych, sygn. 245, Protokół posiedzenia Komitetu Redakcyjnego „Przeglądu Pedagogicznego” z 13 III 1929 r., k. 102-104. 
madzenie TNSW, podczas którego prezes Okręgu Lwowskiego Piotr Zygmunt Dąbrowski złożył wotum nieufności dla Zarządu Towarzystwa. Walne Zgromadzenie odrzuciło wniosek, a Dąbrowskiego poddano ostrej krytyce już w samym Lwowie. W rezultacie ustąpił z prezesury, ale nie tylko ${ }^{27}$. W piśmie Władysława Olszewskiego z Zarządu Okręgu Lwowskiego TNSW do redaktora „Przeglądu Pedagogicznego" z 26 września 1933 roku czytamy, że poprzedni redaktor „Muzeum”, Piotr Zygmunt Dąbrowski, zrezygnował ze stanowiska i nie przekazał Zarządowi Okręgu ani agend, ani portfela redakcyjnego. Uważano, że zniszczył nawet artykuły przeznaczone do druku w kolejnym, wrześniowym zeszycie pisma. Nowy redaktor, Władysław Olszewski, któremu Zarząd Okręgu powierzył wydanie nowego numeru „Muzeum”, znalazł się w bardzo trudnej sytuacji. Uważał, że zebranie nowego materiału będzie trwało do końca października. Wobec tych trudności zwrócił się do redaktora „Przeglądu Pedagogicznego” o pomoc. Pisał: „Przypuszczam, że w redakcji znajdzie się niejeden taki artykuł, który dla jakich bądź przyczyn nie nadaje się do »Przeglądu«, ale nadałby się do »Muzeum«. Czy mógłbym kilka takich artykułów od WPana otrzymać. Ja sam skomunikowałbym się z autorami i postarałbym się o ich zgodę"28.

W dniu 12 września tego roku Zarząd Okręgowy we Lwowie zwolnił też Eugeniusza Kosińskiego, który był administratorem czasopisma. Powodem była m.in. redukcja poborów ${ }^{29}$.

Duga połowa lat trzydziestych to trudny czas dla wydawnictw TNSW. Szczególnie zagrożone wydawało się „Muzeum”, z którym skutecznie konkurował inny kwartalnik TNSW - „Kultura i Wychowanie”30. W preliminarzu budżetowym na 1936 rok odnotowano deficyt. Liczba bezpłatnie rozsyłanych czasopism była zbyt duża ${ }^{31}$. Wpływ na to mogła mieć zmniejszająca się liczba członków Towarzystwa (odchodzących głównie do Związku Nauczycielstwa Polskiego ${ }^{32}$ ), a co za tym idzie spadek dochodów pochodzących ze składek $^{33}$. W związku z tym Zarząd

27 Sprawozdanie Zarządu Głównego TNSW za rok 1933/1934, „Przegląd Pedagogiczny” 1934, nr 5, s. 61 .

${ }^{28}$ AAN, Towarzystwo Nauczycieli Szkół Średnich i Wyższych, sygn. 248, Pismo Władysława Olszewskiego z Zarządu Okręgu Lwowskiego TNSW do Redaktora „Przeglądu Pedagogicznego” z 26 IX 1933 r., b.p.

${ }^{29}$ AAN, Towarzystwo Nauczycieli Szkół Średnich i Wyższych, sygn.. 243, Odpis sprostowania Eugeniusza Kosińskiego do Redakcji „Przeglądu Pedagogicznego”, k. 1.

30 Jego współpracownikami byli uznani uczeni: Florian Znaniecki, Władysław Tatarkiewicz, Sergiusz Hessen, Zygmunt Łempicki, Kazimierz Wyka, Bogdan Nawroczyński. Zob.: B. Łuczyńska, Koło krakowskie TNSW na tle prac Towarzystwa..., s. 124.

${ }^{31}$ AAN, Towarzystwo Nauczycieli Szkół Średnich i Wyższych, sygn. 240, Pismo Zarządu Okręgu Lwowskiego TNSW do Zarządu Głównego TNSW w Warszawie z 3 I 1936 r., k. 128.

32 Jeden cel - dwie metody (Na marginesie odezwy Koła Krakowskiego), „Biuletyn Zarządu Okręgu Poznańskiego Towarzystwa Nauczycieli Szkół Średnich i Wyższych” 1932, nr 1, s. 3.

33 Przykładem zaistniałej sytuacji może być pismo Zarządu Koła Żyrardowskiego TNSW do Zarządu Okręgu Warszawskiego z 1936 roku, w którym czytamy: „W odpowiedzi na pismo Zarządu Okręgu Warszawskiego TNSW Zarząd Koła Żyrardowskiego komunikuje, że obecnie liczba członków Koła wynosi 9 (dziewięć). Staramy się o powiększenie liczby członków Koła drogą osobistej agitacji, z drugiej zaś strony na ostatnim zebraniu Koła uchwalono zwrócić się do Zarządu Okręgu Warszawskiego TNSW z prośbą o przyjście nam w tej sprawie z pomocą. Pomoc ta mogłaby się wyrazić w przyjeździe 
Główny TNSW w Warszawie planował zrezygnować z zasady bezpłatnego dostarczania wydawnictw członkom towarzystwa. Chciano wprowadzić roczną dopłatę 2 zł na koszty druku i wysyłki, zmniejszyć nakłady czasopism i zaprzestać wysyłania wszystkich dotychczasowych tytułów prasowych do członków Towarzystwa. Lwowscy działacze postanowili bronić „Muzeum”. Chcieli nawet doprowadzić do większego uniezależnienia się jego redakcji od Zarządu Głównego. W liście wysłanym do Warszawy zaznaczali, że zgłoszone do 5 grudnia 1935 roku jednorazowe dotacje okręgów i kół już prawie dorównywały preliminowanej kwocie, potrzebnej do wydawania „Muzeum”. W związku z tym Zarząd Okręgu Lwowskiego stał na stanowisku, że zarówno „Kulturę i Wychowanie”, jak i „Muzeum” można nadal rozsyłać członkom bezpłatnie. Lwowscy działacze TNSW uważali, że położenie finansowe Towarzystwa pozwalało zrealizować to nawet w bieżącym roku administracyjnym. Podkreślając wysoką wartość naukową i prestiżową kwartalnika „Kultura i Wychowanie”, Zarząd Okręgu Lwowskiego zaznaczył, że: „dla praktycznego nauczyciela większą użyteczność przedstawia jednak »Muzeum«, niż »Kultura i Wychowanie« oraz że w chwili obecnej, stanowiącej krytyczny i przełomowy moment w dziejach naszego szkolnictwa, bezwarunkowo powinniśmy posiadać pismo, traktujące o aktualnych zagadnieniach życia szkolnego. »Muzeum« jest właśnie w Polsce jedynym tego rodzaju pismem, jeżeli nie weźmiemy pod uwagę »Gimnazjum«, które jednak traktuje wszystkie zagadnienia pedagogiczne z punktu widzenia współzawodniczącej z nami organizacji nauczycielskiej”34.

Zarząd Okręgu Lwowskiego wyrażał przekonanie, że utrzymanie należytego poziomu naukowego i dydaktycznego „Muzeum” zależy od zasobów finansowych wydawnictwa. W związku z tym dotacje na wydawanie, a także honoraria dla redaktorów i autorów powinny być równe we wszystkich wydawnictwach Towarzystwa, przy uwzględnieniu tej samej liczby arkuszy. Zaznaczano, że pomiędzy „Przeglądem Pedagogicznym” a „Muzeum” powinno być przeprowadzone wyraźne rozgraniczenie zainteresowań. Według autorów pisma do Zarządu Głównego, „Przegląd Pedagogiczny” miał być czasopismem ściśle zawodowym, a „Muzeum” pedagogicznym o charakterze „pioniersko-instrukcyjnym” 35 . Ponad-

do Żyrardowa kogoś z kolegów warszawskich i wygłoszeniu odczytu na temat mogący zainteresować ogół nauczycielstwa. Ze swej strony dla ożywienia działalności tutejszego Koła postanowiono sprowadzić z biblioteki Zarządu Okręgu Warszawskiego dzieła o treści naukowej i pedagogicznej. Pierwszy transport książek już został wydany kolegom”. Zarząd Okręgu nie zbagatelizował problemu, a ponieważ proszono jeszcze o konkretne tytuły książek, w odpowiedzi napisano: „Z żądanych książek jedna jest jeszcze w czytaniu, więc tej jeszcze nie przesyłamy, pozostałe otrzymują koledzy, ale bardzo prosimy odesłać nam po przeczytaniu, abyśmy byli w zgodzie z regulaminem lotnych bibliotek. O referenta dla Żyrardowa staramy się i skoro tylko otrzymamy zgodę odpowiedniej osoby, zawiadomimy kolegów. Dla informacji prosimy nam podać, czy lepszy będzie poranek niedzielny, czy sobotni wieczór dla wystąpienia referenta", [w:] AAN, Towarzystwo Nauczycieli Szkół Średnich i Wyższych, sygn. 240, Pismo Zarządu Koła Żyrardowskiego do Zarządu Okręgu Warszawskiego TNSW z 4 XII 1936 r., k. 100; tamże, Pismo Zarządu Okręgu Warszawskiego TNSW do Zarządu Koła Żyrardowskiego [brak daty], k. 101. Zob. też.: Co wynika ze sprawozdań kół?, „Biuletyn Zarządu Okręgu Poznańskiego Towarzystwa Nauczycieli Szkół Średnich i Wyższych” 1932, nr 1, s. 7-8; A. Kołodziejczyk, Towarzystwo Nauczycieli Szkół Średnich i Wyższych..., s. 459.

${ }^{34}$ AAN, Towarzystwo Nauczycieli Szkół Średnich i Wyższych, sygn. 240, Pismo Zarządu Okręgu Lwowskiego TNSW do Zarządu Głównego TNSW w Warszawie z 3 I 1936 r., k. 128-129.

35 Tamże, k. 129. 
to stwierdzono, że Iwowscy działacze TNSW oczekują od Zarządu Głównego TNSW zarządzenia, aby skarbnik towarzystwa w ściśle wyznaczonych terminach przekazywał bezpośrednio do dyspozycji Zarządu Okręgu Lwowskiego fundusz przeznaczony na wydawanie „Muzeum”. Zarząd Okręgu Lwowskiego chciał tymi funduszami dysponować samodzielnie, regulując wysokość ponoszonych wydatków na opłacenie redaktora, autorów, druku, papieru i innych. Lwowscy działacze TNSW przyjmowali też na siebie odpowiedzialność za kierunek rozwoju pisma ${ }^{36}$. Nadmieniano, że to Zarząd Okręgu Lwowskiego wydał ostatnie cztery numery (trzy zeszyty) „Muzeum”. W związku z tym domagano się od Zarządu Głównego zwrotu kwot wydanych na czasopismo w 1935 roku. Podkreślano, że wydanie tych czterech numerów pozwoliło utrzymać ciągłość pisma i przysłużyło się „Towarzystwu i szkole polskiej w przełomowej chwili jej rozwoju" ${ }^{37}$. Ponadto stwierdzano, że:

Zarząd Okręgu Lwowskiego, wysłuchawszy na dwóch posiedzeniach szczegółowego sprawozdania z przebiegu obrad pełnego Zarządu Głównego [w Warszawie] w dniu 10. listopada 1935, nie może się powstrzymać od wyrażenia zdziwienia i żalu z powodu rażąco nierównomiernego traktowania „Muzeum” w zakresie finansowym (25\% kwoty, preliminowanej przez Walne Zgromadzenie na „Muzeum" - 108\% kwoty preliminowanej na „Przegląd Pedagogiczny”), którego nie można usprawiedliwić rzekomo niskim poziomem tego wydawnictwa ${ }^{38}$.

Jednak Zarząd Główny TNSW w Warszawie nie zgodził się z tymi propozycjami, zwłaszcza co do spraw finansowych. W dniu 23 stycznia 1936 roku do Zarządu Okręgowego TNSW we Lwowie skierowano pismo, w którym informowano, że w dniu 16 stycznia 1936 roku uchwalono preliminarz budżetowy według założeń Skarbnika Zarządu Głównego. W piśmie wysłanym do Lwowa czytamy, że według zatwierdzonego preliminarza w roku bieżącym wydawane będą oba kwartalniki, lecz tylko jeden z nich będzie dostarczany członkom bezpłatnie. Miało to nastąpić zgodnie z wyborem samych czytelników. Dopiero w przypadku braku takiej decyzji ze strony członka, Administracja Wydawnictw miała sama wyznaczyć pismo, kierując się zasadą, aby liczby egzemplarzy dostarczanych bezpłatnie jednego i drugiego kwartalnika były mniej więcej równe. Drugi kwartalnik członkowie mieli odtąd otrzymywać za dopłatą 2 zł rocznie na koszty naddruku i wysyłki. W sprawie wyboru pism, za pośrednictwem „Przeglądu Pedagogicznego”, zarządzono ankietę. Proszono Okręg Lwowski o opracowanie i nadesłanie w najbliższym czasie szczegółowego projektu wydatków na „Muzeum” w całym 1936 roku, przy uwzględnieniu nakładu 2000 egzemplarzy o objętości 16 arkuszy w 4 zeszytach. Zaproponowano terminy wydawnicze na: koniec marca, koniec maja, koniec września i koniec listopada ${ }^{39}$. A celem ostatecznego rozliczenia

36 Tamże, k. 129-130.

${ }^{37}$ AAN, Towarzystwo Nauczycieli Szkół Średnich i Wyższych, sygn. 240, Ciąg dalszy pisma I.4/36 Zarządu Okręgu Lwowskiego TNSW do Zarządu Głównego TNSW w Warszawie z 3 I 1936 r., k. 88.

38 Tamże.

39 Później starano się koordynować termin ukazywania się „Muzeum” i „Kultury i Wychowania”. Ukazywały się w następującym porządku: koniec stycznia - $1 \mathrm{nr}$ „Muzeum”, koniec lutego - $1 \mathrm{nr}$ „Kultury i Wychowania”, koniec marca - 2 nr „Muzeum”, około 10 maja - 2 nr „Kultury i Wychowania”, po- 
kosztów wydawania "Muzeum" w 1935 roku proszono o nadesłanie szczegółowego sprawozdania z wydatków. Potrzebę takiego rozliczenia argumentowano $w$ ten sposób, że w dochodach z prenumeraty i ogłoszeń w „Muzeum” przewidziano kwotę 1000 zł, ale najprawdopodobniej suma ta znacznie wzrosła, gdyż podana w liście przez redaktora Olszewskiego liczba prenumeratorów wynosiła przeszło 250. W związku z tym proszono o dokładne zestawienie dochodów „Muzeum” za 1935 rok, zarówno już otrzymanych, jak i tych mających dopiero wpłynąć do kasy redakcji ${ }^{40}$. Jak można wnioskować, Zarząd Główny w Warszawie nie pozwalał Iwowskim działaczom na zbyt dużą swobodę finansową i ściśle kontrolował finanse redakcji „Muzeum”, a próba wyjścia spod tej kontroli nie powiodła się.

Ponownie w trudnej sytuacji kwartalnik „Muzeum” znalazł się tuż przed wybuchem II wojny światowej. W dniu 31 sierpnia 1939 roku Administracja "Muzeum” i Zarząd Okręgu Lwowskiego TNSW informowały Zarząd Główny TNSW w Warszawie o wstrzymaniu druku kolejnego numeru. Proszono o opłacenie w drukarni rachunku za zrobiony już skład. Powodem najprawdopodobniej był brak funduszy na druk i kolportaż „Muzeum”. Pismo doręczono jeszcze do Zarządu Głównego 5 września 1939 roku, czyli w pierwszych dniach wojny ${ }^{41}$. Jednak działania wojenne przekreśliły wszelkie oficjalne działania edytorskie TNSW, a powyższe problemy przestały być aktualne.

$\mathrm{Na}$ uwagę zasługuje poruszana wyżej finansowa strona funkcjonowania Towarzystwa. Z dokumentów wytworzonych w 1938 roku przez Główną Komisję Rewizyjną wynika, że księgowość w TNSW stała na bardzo wysokim poziomie, „Księgi prowadzone są we wzorowym porządku”42. Odnotowano wzrost wydatków na wydawnictwa, co wynikało ze zwiększenia liczby arkuszy wydawniczych poszczególnych tytułów i wydania dodatkowych numerów „Kultury i Wychowania”, a także „Przeglądu Pedagogicznego”. Komisja w protokole stwierdzała, że „wydatkowanie było racjonalne, oględne i zgodne z uchwalonym preliminarzem" ${ }^{3}$.

Oprócz zestawień finansowych redakcje składały sprawozdania ze swojej działalności programowej. W jednym z nich, dotyczącym „Muzeum”, raportowano:

Kontynuując dotychczasową linię programową wydawnictwo starało się o aktualizowanie treści w odniesieniu do najbardziej piekących zagadnień współczesnego szkolnictwa średniego ogólnokształcącego. Między innymi omówiono zagadnienie szkoły i Państwa oraz wychowania oby-

łowa września - $3 \mathrm{nr}$ „Muzeum”, połowa października - $3 \mathrm{nr}$ „Kultury i Wychowania”, połowa listopada $-4 \mathrm{nr}$ „Muzeum”, połowa grudnia - $4 \mathrm{nr}$ „Kultury i Wychowania”. Zob.: AAN, Towarzystwo Nauczycieli Szkół Średnich i Wyższych, sygn. 240. Terminy wydawania kwartalników w 1937 roku, k. 303.

${ }^{40}$ AAN, Towarzystwo Nauczycieli Szkół Średnich i Wyższych, sygn. 240, Pismo Skarbnika Zarządu Głównego TNSW w Warszawie do Zarządu Okręgowego TNSW we Lwowie z 23 I 1936 r., k. 102-103.

${ }^{41}$ AAN, Towarzystwo Nauczycieli Szkół Średnich i Wyższych, sygn. 240, Pismo Administracji „Muzeum” Czasopisma poświęconego sprawom wychowania i szkolnictwa. Zarządu Okręgu Lwowskiego TNSW do Zarządu Głównego TNSW w Warszawie z 31 VIII 1939 r., k. 390; tamże, Pismo wiceprezesa TNSW [brak imienia i nazwiska] do redaktora prof. Kazimierza Brończyka we Lwowie z 25 VIII 1939 r., k. 389.

42 AAN, Towarzystwo Nauczycieli Szkół Średnich i Wyższych, sygn. 244, Protokół Głównej Komisji Rewizyjnej z 20 II 1938 r., k. 66.

${ }^{43}$ Tamże. 
watelskiego [...], problem selekcji [...], kwestię samodzielności [...], sprawę praktyki przedegzaminacyjnej kandydatów na nauczycieli szkół średnich [...], sprawę trudności w realizacji programów gimnazjalnych [...]. W dziale sprawozdawczym podano wyniki ankiety w sprawie nauczania języka polskiego w klasach I-IV [...]. Poza tym poruszono także sprawę uposażeniową nauczycielstwa szkół średnich [...]. Redakcja starała się wciągnąć do współpracy autorów pochodzących z różnych dzielnic kraju. llość prenumeratorów stale wzrasta ${ }^{44}$.

\section{W innym zestawieniu czytamy:}

„Przegląd Pedagogiczny” od 1 maja 1937 r. do 15 lutego 1938 r. w szesnastu numerach zawiera artykuły poświęcone wychowaniu i nauczaniu, projektom programów liceum ogólnokształcącego, wynikom nauczania w gimnazjum, sprawie matury, niektórym zagadnieniom polityki szkolnej (budżet, wykształcenie młodzieży wiejskiej), a przede wszystkim sprawom stanu nauczycielskiego: obronie jego praw (sprawy uposażeniowe i emerytalne), brakowi etatów, opiece nad nauczycielami pracującymi naukowo, problemowi pragmatyki dla nauczycieli szkół prywatnych, nadania umowie zbiorowej MKN mocy powszechnie obowiązującej, doli młodego nauczycielstwa, zagadnieniu jego praktyki przedegzaminowej. Nadto umieszczaliśmy sprawozdania ilustrujące niektóre kongresy i zjazdy, jubileusze i uroczystości szkolne. Od czasu do czasu umieszczaliśmy artykuły związane ze szkolnictwem zagranicznym, podawaliśmy głosy prasy o szkole i nauczycielu. Wreszcie każdy numer przynosił artykuły informujące członków o działalności Towarzystwa [... $]^{45}$.

Przedstawione sprawozdania głównych tytułów prasowych TNSW pokazują, jakie spektrum problematyki nauczycielskiej obejmowały te wydawnictwa, tylko w tych dwóch przypadkach. Biorąc pod uwagę całą aktywność wydawniczą Towarzystwa: jego udział w sukcesie spółki „Książnica-Atlas TNSW”, wydawane podręczniki, poradniki, liczne czasopisma specjalistyczne, publikacje adresowane do młodzieży, to skala tej działalności edytorskiej musi być oceniona wysoko.

Oczywiście wśród członków TNSW, oficjalnie apolitycznego, nie brakowało sporów natury politycznej. Część działaczy pozostawała pod wyraźnymi wpływami narodowej demokracji, byli też zwolennicy chrześcijańskiej demokracji i spora grupa zwolenników sanacji (w latach trzydziestych) ${ }^{46}$. Jednak starano się łagodzić konflikty natury politycznej i skupiać się na pracy merytorycznej. Można to zaobserwować w wydawnictwach. Podczas posiedzenia Komitetu Redakcyjnego „Przeglądu Pedagogicznego" w pierwszych dniach po przewrocie majowym 1926 roku trudno znaleźć ślady tych wydarzeń, najpewniej dyskusji o charakterze politycznym nie protokołowano. W protokołach znajduje się tylko informacja, że Redakcja zamierza zamieścić w 22 numerze pisma Okólnik Ministra Wyznań i Oświecenia Publicznego Józefa Mikułowskiego-Pomorskiego w sprawie rozpolitykowania młodzieży. Postanowiono dodać komentarz, że „Przegląd Pedagogiczny” poruszał sprawę już wcześniej ${ }^{47}$. W TNSW do prawdziwej próby sił na tle politycznym

${ }^{44}$ AAN, Towarzystwo Nauczycieli Szkół Średnich i Wyższych, sygn. 244, „Muzeum” Sprawozdanie (prawdopodobnie z 1938 r.), k. 58.

${ }^{45}$ AAN, Towarzystwo Nauczycieli Szkół Średnich i Wyższych, sygn. 244, Sprawozdanie Redakcji „Przeglądu Pedagogicznego” za okres od 1 V 1937 r. do 15 II 1938 r., k. 59.

${ }^{46}$ B. Łuczyńska, Koło krakowskie TNSW na tle prac Towarzystwa..., s. 140; A. Kołodziejczyk, Towarzystwo Nauczycieli..., s. 459.

${ }^{47}$ AAN, Towarzystwo Nauczycieli Szkół Średnich i Wyższych, sygn. 246, Protokół posiedzenia Komitetu Redakcyjnego „Przeglądu Pedagogicznego" z 10 VI 1926 r., b.p. 
doszło w pierwszej połowie lat trzydziestych. W 1932 roku na Walnym Zgromadzeniu działacze Koła Krakowskiego podjęli próbę upolitycznienia Towarzystwa i zgłosili wniosek o usunięcie ze statutu zapisu o apolityczności organizacji. Stało się tak na skutek negatywnego stosunku wielu delegatów do nowej ustawy o ustroju szkolnictwa (ustawa jędrzejewiczowska z 11 marca 1932 roku), o projekcie której TNSW już wcześniej wypowiedziało się krytycznie, także przed komisją sejmową ${ }^{48}$. Początkowo spór udało się załagodzić, ale tylko tymczasowo. W 1934 roku na skutek konfliktu pomiędzy zwolennikami narodowej demokracji a silną frakcją sanacyjną doszło do rozłamu w Towarzystwie. Secesjoniści utworzyli Zrzeszenie Nauczycieli Szkół Średnich i Wyższych (ZNSW). Jednak rozłam nie trwał długo i 1 listopada 1935 roku ponownie połączono obie organizacje ${ }^{49}$.

Dwa lata później umiejętnie odniesiono się do faktu powstania Obozu Zjednoczenia Narodowego. W artykule „Przeglądu Pedagogicznego” pt. TNSW a OZN czytamy:

Towarzystwo Nauczycieli Szkół Średnich i Wyższych w myśl swego statutu jest apolityczne, nie ma tedy prawa zgłaszać akcesu do Obozu o charakterze politycznym. Jednakże pragniemy stwierdzić, iż deklaracja pułkownika [Adama] Koca, stanowiąca podstawy Obozu Zjednoczenia Narodowego, zawiera te same zasady wychowania narodowego i religijnego, o które organizacja nasza z niezłomną wytrwałością wśród największych przeciwieństw, nie cofając się przed wielu ofiarami, walczy z górą pół wieku ${ }^{50}$.

TNSW wyraźnie dążyło do zachowania kompromisu w relacjach z władzami, co zapewniało możliwość działania i ciągle silną pozycję wśród nauczycieli.

W ocenie działalności Towarzystwa nie należy zapominać, że TNSW podejmowało szereg innych zadań w zakresie organizacji pomocy nauczycielom w doskonaleniu się w zawodzie (np. organizowanie kursów, prowadzenie bibliotek i czytelni), organizacji pomocy prawno-społecznej (np. interwencje w sprawach nauczycieli w kuratoriach i Ministerstwie Wyznań i Oświecenia Publicznego) ${ }^{51}$, pomocy w znalezieniu pracy (np. poprzez działalność Społecznego Biura Pośrednictwa Pracy przy Okręgu Warszawskiem TNSW) ${ }^{52}$, organizacji samopomocy materialnej, takiej jak np. korzystanie z szeregu funduszy (w czasie wielkiego kryzysu gospodarczego Zarząd Główny TNSW postanowił o przekazaniu dywidendy od akcji „Książnicy-Atlasu” z 1931 roku na fundusz bezrobocia) ${ }^{53}$. Ślady tej dzia-

48 Jeden cel-dwie metody (Na marginesie odezwy Koła Krakowskiego), „Biuletyn...”, s. 1-3.
${ }^{49}$ B. Łuczyńska, Koło krakowskie TNSW na tle prac Towarzystwa..., s. 139-149.
50 TNSW a OZN, „Przegląd Pedagogiczny” 1937, nr 5, s. 1.
51 J. Szafran, Dla dobra polskiej szkoły..., s. 157-158; B. Łuczyńska, Koło krakowskie TNSW na tle prac Towarzystwa..., s. 125-126.

52 AAN, Towarzystwo Nauczycieli Szkół Średnich i Wyższych, sygn. 240, Druk pisma Społecznego Biura Pośrednictwa Pracy przy Okręgu Warszawskiem TNSW do dyrekcji ... [nie podano nazwy instytucji, brak daty], k. 101v.

53 Walne Zgromadzenie Okręgu i jego echa na Walnym Zgromadzeniu Towarzystwa, „Biuletyn Zarządu Okręgu Poznańskiego Towarzystwa Nauczycieli Szkół Średnich i Wyższych” 1932, nr 1, s. 4; J. Szafran, Dla dobra polskiej szkoły..., s. 158; B. Łuczyńska, Koło krakowskie TNSW na tle prac Towarzystwa..., s. 131-139. 
łalności znajdują się w wielu wydawnictwach TNSW, często w postaci ogłoszeń, sprawozdań, kronik.

TNSW, mimo licznych utrudnień wynikających z potrzeby scalenia polskiej edukacji w jeden system po latach zaborów ${ }^{54}$, zmiennej koniunktury gospodarczej, sporych zmian politycznych w II RP, utrzymało wysoki poziom swych publikacji. Zarząd Główny Towarzystwa potrafił umiejętnie sprawować kontrolę nad poszczególnymi sferami tak szerokiej działalności edytorskiej. Systematycznie realizowano założenie poszerzania wiedzy i jej popularyzacji. Wspierano rozwój pedagogiczny i naukowy nauczycieli, wspomagano pracę szkół. W tym celu współpracowano z ogromną rzeszą wybitnych specjalistów i ludzi oddanych idei tworzenia polskiego szkolnictwa na jak najwyższym poziomie. Wkład Towarzystwa w rozwój polskiej oświaty można uznać za imponujący. TNSW, pomimo wielu wskazanych powyżej trudności, prowadziło niezwykle skutecznie swoją działalność edytorską, zajmując dominującą pozycję na rynku wydawniczym II Rzeczypospolitej.

54 „Zjednoczenie szkolnictwa różnych dzielnic, budowa zupełnie nowego gmachu odrodzonej szkoły polskiej, na gruzach szkoły obcej" stanowiło szczególny powód dumy w końcu dwudziestolecia międzywojennego. Zob.: 1918-1938, „Przegląd Pedagogiczny” 1938, nr 23, s. 334-335. 